\title{
Review on micro-direct methanol fuel cells
}

\author{
D.S. Falcão ${ }^{a, *}$, V.B. Oliveira ${ }^{a}$, C.M. Rangel ${ }^{b}$, A.M.F.R. Pinto ${ }^{a, *}$ \\ ${ }^{a}$ CEFT, Departamento de Eng. Química, Universidade do Porto, Faculdade de Engenharia, Rua Dr. Roberto Frias, $4200-465$ Porto, Portugal \\ ${ }^{\mathrm{b}}$ LNEG, Estrada do Paço do Lumiar, 22 1649-038 Lisboa, Portugal
}

\section{A R T I C L E I N F O}

\section{Article history:}

Received 30 July 2012

Received in revised form

10 January 2014

Accepted 1 March 2014

Available online 20 March 2014

Keywords:

Micro-direct methanol fuel cells

Modeling

Operating conditions

Review

\begin{abstract}
A B S T R A C T
Fuel cells have unique technological attributes: efficiency, minimization of moving parts and low emissions. The Direct Methanol Fuel Cell (DMFC) has attracted much attention due to its potential applications as a power source for transportation and portable electronic devices. With the advance of micromachining technologies, miniaturization of power sources became one of the trends of evolution of research in this area. Based on the advantages of the scaling laws, miniaturization promises higher efficiency and performance of power generating devices, so, MicroDMFC is an emergent technology. There has been a growing interest in the development of this type of micro cells in the last years, resulting both in experimental studies (operating conditions, cell design and new materials) and in modeling studies. Despite the increase in the knowledge acquired, many challenges are still to be reached. This paper provides a detailed comprehensive review both on fundamental and technological aspects of micro-direct methanol fuel cells. Special attention is devoted to systematization of published results on experimental area since to date and also to a special section dedicated to modeling studies.
\end{abstract} (c) 2014 Elsevier Ltd. All rights reserved.

\section{Contents}

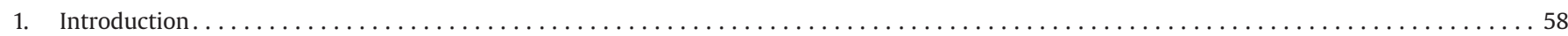

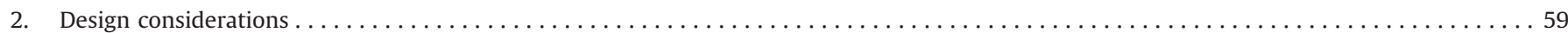

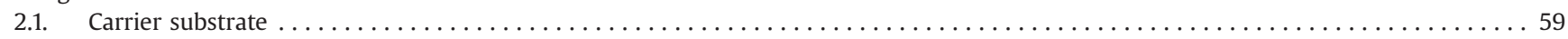

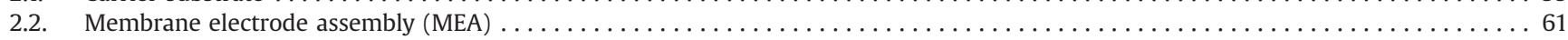

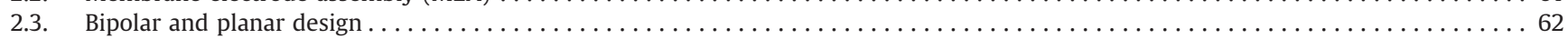

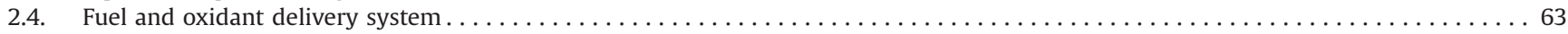

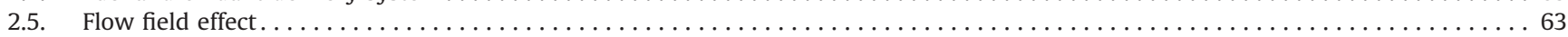

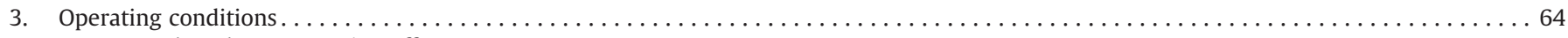

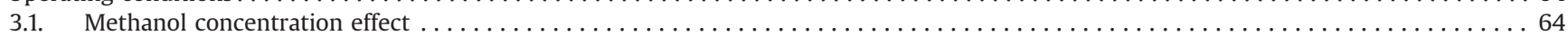

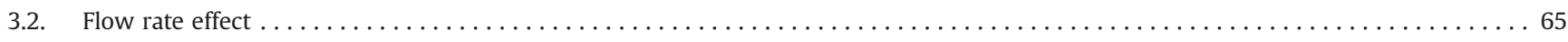

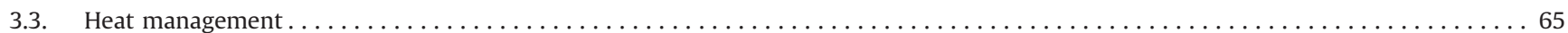

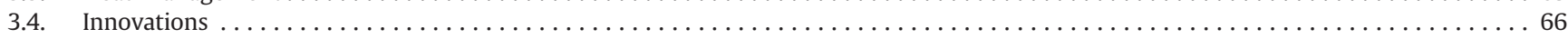

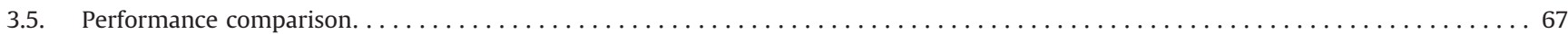

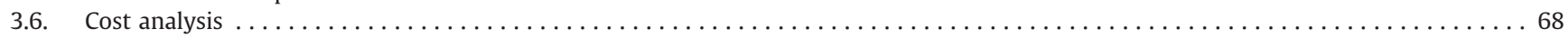

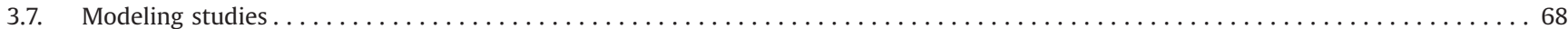

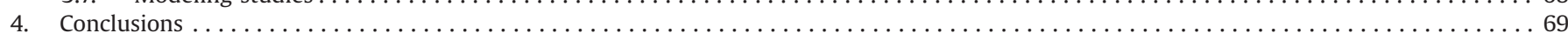

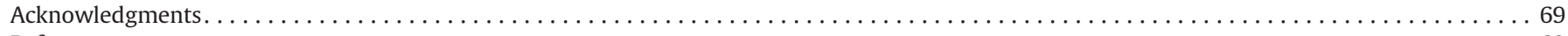

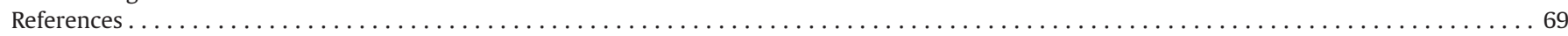

\footnotetext{
* Corresponding authors. Tel.: +351 225081675; fax: +351 225081449 .

E-mail addresses: dfalcao@fe.up.pt (D.S. Falcão), apinto@fe.up.pt (A.M.F.R. Pinto).
}

\section{Introduction}

Nowadays, consumers demand for portable, power-hungry devices (3G-cellular phones, laptop computers and internetenabled PDAs) has stimulated researchers and industry to develop 